\title{
Article
}

\section{Infrastructure and Economic Growth}

\author{
Markus Brueckner
}

check for

updates

Citation: Brueckner, Markus. 2021 Infrastructure and Economic Growth. Journal of Risk and Financial Management 14: 543. https:// doi.org/10.3390/jrfm14110543

Academic Editor: Mark Harris

Received: 6 September 2021

Accepted: 4 October 2021

Published: 11 November 2021

Publisher's Note: MDPI stays neutral with regard to jurisdictional claims in published maps and institutional affiliations.

Copyright: (C) 2021 by the author. Licensee MDPI, Basel, Switzerland. This article is an open access article distributed under the terms and conditions of the Creative Commons Attribution (CC BY) license (https:// creativecommons.org/licenses/by/ $4.0 /)$.
Research School of Economics, Australian National University, LF Crisp Building 26A, Canberra, ACT 0200, Australia; markus.brueckner@anu.edu.au

\begin{abstract}
I estimate the effect that growth in countries' GDP per capita has on the growth rate of infrastructure. In order to extract exogenous variation in GDP per capita growth, I use the growth of the international oil price multiplied with countries' GDP shares of oil net-exports as an instrumental variable. My instrumental variables estimates show that, for both democracies and autocracies, GDP per capita growth has a significant positive effect on infrastructure growth. This effect is significantly smaller in anocracies-so much so that, in anocracies, GDP per capita growth has no significant effect on the growth rate of infrastructure.
\end{abstract}

Keywords: anocracy; economic growth; infrastructure

JEL Classification: H5; P1

\section{Introduction}

Infrastructure is useful for economic development. Recent empirical studies have documented a significant positive effect of infrastructure on aggregate output, with a longrun elasticity of around 0.1 (Calderón et al. 2015). Donaldson (2018) examines the impact of transportation infrastructure in colonial India and documents that the positive effect on output arises due to transportation infrastructure reducing trade costs which, in turn, facilitates domestic and international trade. In international organizations, a significant amount of finance has been allocated to building infrastructure in developing countries (see, e.g., IADB 2013; UN 2009; World Bank 2009).

If infrastructure is useful for a country's economic development, then the question arises as to what are its determinants. In this paper, I explore one particular determinant of infrastructure growth, namely, growth in the national income of a country that is due to an exogenous (external) shock. The type of exogenous shock that I focus on is a shock to a country's terms of trade arising from a change in the international oil price. Key features of oil that make me focus on this variable of interest are that: (i) variations in the international oil price are persistent (during 1960-2010, the AR (1) coefficient over a 10-year period is around 0.9), hence this variable is a suitable (relevant) instrument for GDP per capita growth; (ii) the majority of countries in the world are price takers (see e.g., Hamilton 2013) so that variations in the international oil price can be thought of as a plausibly exogenous source of variation in countries' GDP per capita growth.

Based on a panel of 141 countries, I find that, on average, infrastructure growth increases in response to growth in GDP per capita. My instrumental variables' estimates show that, for the average country in the sample, a one percentage point increase in real GDP per capita growth over a 10-year period increases the growth rate of transportation infrastructure by 0.5 percentage points, telecommunications infrastructure by 0.4 percentage points, and water and sanitation infrastructure by 0.1 and 0.2 percentage points, respectively.

The finding of a significant positive average response of infrastructure growth to GDP per capita growth is an important result as it suggests that, in the majority of countries, exogenous income gains were used to pave the way for future economic development. Infrastructure is durable in nature. The additional income was invested in infrastructure, and this enabled higher output per worker in the future. 
The positive average response of infrastructure growth to GDP per capita growth masks heterogeneity in that response across countries and time. While it is not feasible to estimate the infrastructure response to GDP per capita growth for each country-time observation, I can examine heterogeneity regarding the effect of GDP per capita growth on infrastructure growth that arises from country-specific characteristics.

One country-specific characteristic that is likely to matter is the political regime. The political regime matters because infrastructure development is, to a large extent, a responsibility of governments ${ }^{1}$. There exists a well-established literature at the intersection of economics and political science examining how the political regime affects economic outcomes. In this literature, the extent to which democracy has superior effects on countries' economic development is still debated ${ }^{2}$. I contribute to that literature by examining how the political regimes affect the response of infrastructure growth to plausibly exogenous GDP growth, driven by variations in international oil prices.

In my empirical analysis, I group countries into democracies, anocracies, and autocracies based on the widely used Polity IV (2013) data and classification scheme ${ }^{3}$. I find that: (i) GDP per capita growth has a significant positive effect on infrastructure growth in democracies and autocracies; (ii) the impact of GDP per capita growth on infrastructure growth is quantitatively small and statistically insignificant in anocracies.

In order to understand the above result, it is helpful to clarify the key characteristics of anocracy and infrastructure. According to Polity IV (2013), anocracies are countries that very often reflect inherent qualities of instability and are especially vulnerable to the onset of new political instability events, such as outbreaks of armed conflict, unexpected changes in leadership, or adverse regime changes (e.g., a seizure of power by a personalistic or military leader). Infrastructure, by its nature, is durable. The development of infrastructure is primarily a decision problem of governments; it is not a decision problem of the private sector.

The durable characteristic of infrastructure implies that aggregate output will be higher in the future. In the future, however, a political leader of an anocratic regime is unlikely to be in power. The political leader in an anocratic regime will therefore reap relatively little benefit from spending additional income gains on infrastructure. Instead, the political leader can obtain substantial immediate gains by spending the additional income on consumption.

The empirical results in my paper also speak to the literature on the politico-economic effects of oil. Alexeev and Conrad (2009) showed that, in the cross-section of countries, oil wealth leads to significantly higher levels of GDP per capita. Using panel regressions and controlling for country and time fixed effects, as I do in this paper, Haber and Menaldo (2011) showed that there is no evidence of oil rents having a detrimental effect on political institutions. My paper contributes to that literature by examining the impact of oil price shocks on an important variable for economic development-infrastructure-and how this impact depends on countries' political regime. Overall, my findings do not support the argument—articulated, for example, by Ross (2012) — that income from oil is a curse. In autocracies and democracies, a significant part of the income gains from plausibly exogenous international oil price booms are allocated to expand infrastructure. Only in anocracies do income gains from oil price booms have no significant effect on infrastructure growth.

The remainder of the paper is organized as follows: Section 2 discusses the estimation strategy. Section 3 describes the data. Section 4 presents the main results. Section 5 presents the conclusions.

\section{Estimation Strategy}

The estimating equation relates the growth rate of infrastructure to the growth rate of real GDP per capita over a 10-year period:

$$
\Delta \ln \left(\text { Infrastructure }_{i t}\right)=a_{i}+b_{t}+\alpha \Delta \ln (\text { GDP p.c.it })+e_{i t}
$$


where $a_{i}$ are country fixed effects; $b_{t}$ are time fixed effects; and $e_{i t}$ is an error term. In the above equation, $\alpha$ captures the average response of infrastructure growth to GDP per capita growth. The computed standard error on $\alpha$ is Huber robust and clustered at the country level; clustering at the country level allows for arbitrary serial correlation of the residual within countries.

Least squares estimation of $\alpha$ is likely to produce inconsistent estimates due to the endogeneity of GDP per capita growth. Infrastructure's positive effect on GDP per capita implies that least squares estimation overstates the response of infrastructure growth to GDP per capita growth. Measurement error, if random, implies that the least squares estimate of $\alpha$ is attenuated towards zero. It is therefore unclear whether least squares estimates of $\alpha$ are upward or downward biased. Of course, time-varying omitted variables can bias the least squares estimate on $\alpha$ in any direction.

Instrumental variables' estimation provides a consistent estimate of $\alpha$, provided that the instrument for GDP per capita growth is relevant and uncorrelated with the secondstage error term. The criterion of instrument relevance is that the instrument's first-stage effect on GDP per capita growth is sufficiently precise, i.e., the Kleibergen Paap F-statistic should be in excess of $10 .{ }^{4}$ For the instrument to be uncorrelated with the second-stage error term, the instrument should be: (i) exogenous; and (ii) only affect infrastructure growth through GDP per capita growth.

The first stage in the two-stage least squares estimation is:

$$
\Delta \ln (\text { GDP p.c.it })=c_{i}+d_{t}+\beta O P S_{i t}+u_{i t}
$$

where OPS is the change in the natural logarithm of the international oil price over a 10 -year period, $\Delta \mathrm{P}_{\mathrm{t}}$, weighted with countries' average GDP shares of oil net exports, $\theta_{\mathrm{i}}$.

It is important to note that the econometric model includes country fixed effects, $c_{i}$, and time fixed effects, $d_{t}$. The coefficient $\beta$ thus measures the within-country effect of OPS on GDP per capita growth. The sign of $\beta$ is expected to be positive due to the standard terms-of-trade effect.

\section{Data}

Infrastructure. Data on infrastructure are from the World Bank (2013). Following Calderón et al. (2015), I use data on real measures of infrastructure, i.e., roads, telephones lines, and the share of population with access to improved water and sanitation facilities. An alternative to using real measures of infrastructure would be to use (flow) measures of public investment. Research by Pritchett (2000) and Keefer and Knack (2007) suggests, however, that, in countries with weak institutions, public investment only imperfectly translates into changes of physical capital. Ultimately, it is physical capital (and not investment) that is useful for economic development, enabling higher real output in the future.

In my empirical analysis, I will focus on three different types of infrastructure: telecommunications infrastructure, transportation infrastructure, water and sanitation infrastructure. My main measure of telecommunications infrastructure is telephones lines per capita. Other measures of telecommunications infrastructure are mobile phones per capita and internet users per capita. For transportation infrastructure, my main measure is the total network of roads. Other measures of transportation infrastructure are the share of paved roads and the total route of railway lines. For water infrastructure, my main measure is the percentage of the population with access to an improved drinking water source. My main measure for sanitation infrastructure is the percentage of the population with access to improved sanitation facilities.

Anocracy. The Polity IV project assigns countries a so-called Polity2 score that is based on political constraints, political competition, and executive recruitment. Anocracies are countries with a Polity2 score of -6 to 6 ; democracies (autocracies) are countries with a Polity 2 score of 7 or above ( -7 and below). Figure 1 displays the time-series evolution of the number of countries in the world that are democracies, autocracies, and anocracies. 


\section{Global Trends in Governance, 1800-2017}

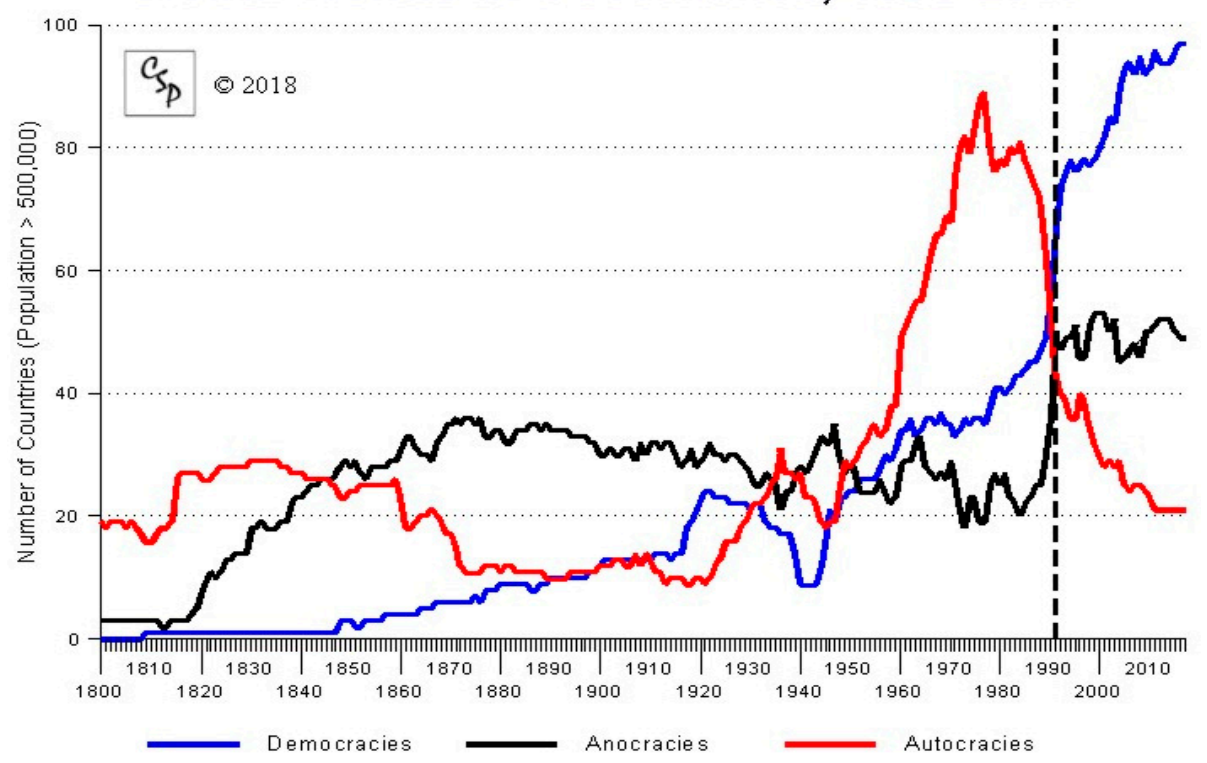

Figure 1. Source: Polity IV (2013). Downloaded from http:/ / www.systemicpeace.org/polity / polity1 .htm (accessed on 27 September 2021).

According to Polity IV (2013), anocracies are characterized by institutions and political elites that are far less capable of performing fundamental tasks and ensuring their own continuity; they very often reflect inherent qualities of instability or ineffectiveness and are especially vulnerable to the onset of new political instability events, such as outbreaks of armed conflict, unexpected changes in leadership, or adverse regime changes (e.g., a seizure of power by a personalistic or military leader). Over fifty percent of anocracies experience a major regime change within five years and over seventy percent within ten years. Anocracies have been much more vulnerable to new outbreaks of armed societal conflict: about six times more likely than democracies and two and one-half times as likely as autocracies to experience new outbreaks of societal wars.

GDP per capita and Terms of Trade Growth. Data on PPP GDP per capita are from the Penn World Table, version 7.1 (Heston et al. 2012). Data on the net barter terms of trade are from the World Bank (2013).

OPS. The oil price shock (OPS) instrument is constructed as $\mathrm{OPS}_{\mathrm{it}}=\Delta \ln \left(\mathrm{P}_{\mathrm{t}}\right) * \theta_{\mathrm{i}}$, where $\Delta \ln \left(P_{t}\right)$ is the change in the natural logarithm of the international oil price over a 10 -year period and $\theta_{\mathrm{i}}$ is country i's average share of oil net exports in GDP. Data on exports and imports of oil are from Feenstra et al. (2004). Data on the international oil price are from UNCTAD (2011).

For descriptive statistics see Table 1. 
Table 1. Descriptive statistics.

\begin{tabular}{lll}
\hline Variable & Mean & Standard Deviation \\
\hline$\Delta \ln$ (Telephone Lines p.c.) & 0.07 & 0.10 \\
$\Delta \ln$ (Mobile Phones p.c.) & 0.51 & 0.46 \\
$\Delta \ln$ (Internet Users p.c.) & 0.55 & 0.58 \\
$\Delta \ln$ (Roads p.c) & 0.01 & 0.05 \\
$\Delta \ln$ (Railway Lines p.c) & -0.01 & 0.31 \\
$\Delta(\%$ Paved Roads) & 0.26 & 2.26 \\
$\Delta(\%$ People Access Sanitation Facilities $)$ & 0.49 & 0.82 \\
$\Delta(\%$ People Access Water $)$ & 0.58 & 0.81 \\
GDP p.c. growth & 0.06 & 0.04 \\
$\Delta$ Terms of Trade Index & -0.03 & 0.15 \\
$\Delta \ln ($ Terms of Trade Index $)$ & -0.02 & 0.13 \\
OPS & 0.00 & 0.03 \\
\hline
\end{tabular}

\section{Main Results}

\subsection{Average Response of Infrastructure to GDP p.c. Growth}

Table 2 presents least squares estimates of the relationship between infrastructure growth and GDP per capita growth. In column (1) of Table 2, the dependent variable is the change in the log of the total network of roads. In column (2) of Table 2, the dependent variable is the change in the log of telephone lines. In column (3) of Table 2, the dependent variable is the change in the share of people with access to improved sanitation facilities. In column (4) of Table 2, the dependent variable is the change in the share of people with access to improved water facilities. The main result of the least squares regressions, see Table 2, is that there is a significant positive within-country relationship between GDP per capita growth and the growth rate of telephone lines and sanitation facilities; there is no significant within-country relationship between GDP per capita growth and the growth rate of roads and water access ${ }^{5}$.

Table 2. GDP growth and infrastructure: (least squares estimates).

\begin{tabular}{ccccc}
\hline Dependent Variable Is: & $\boldsymbol{\Delta} \ln ($ Roads p.c.) & $\Delta \ln$ (Tel. Lines p.c.) & $\begin{array}{c}\Delta(\% \text { People Access } \\
\text { Sanitation Facilities) }\end{array}$ & $\begin{array}{c}\Delta(\% \text { People Access } \\
\text { Water) }\end{array}$ \\
\hline & $(1)$ & $(2)$ & $(3)$ & $(4)$ \\
LS & $2.12 * *$ & -0.41 \\
GDP p.c. growth & LS & LS & $(0.79)$ & $(0.80)$ \\
Country FE & $(0.10)$ & $(0.08)$ & Yes & Yes \\
Year FE & Yes & Yes & Yes & Yes \\
Observations & Yes & 3725 & 2161 & 2143 \\
\hline
\end{tabular}

Note: The method of estimation is least squares. Huber robust standard errors (shown in parentheses) are clustered at the country level.

* Significantly different from zero at the 10 percent significance level, ${ }^{* *} 5$ percent significance level, ${ }^{* * *} 1$ percent significance level.

Table 3 presents the baseline two-stage least squares (2SLS) estimates. Panel A shows that, for all measures of infrastructure, the second-stage coefficient on GDP per capita growth is positive and significantly different from zero at the conventional significance levels. Quantitatively, the instrumental variables' estimates suggest that a one percentage point increase in GDP per capita growth: (i) increases the growth rate of roads by 0.5 percentage points; (ii) increases the growth rate of telephone lines by 0.4 percentage points; and (iii) increases the growth rate of the share of the population with access to sanitation (water) facilities by $0.07(0.03)$ percentage points. 
Table 3. GDP growth and infrastructure (2SLS Estimates).

\begin{tabular}{|c|c|c|c|c|}
\hline Dependent Variable Is: & $\Delta \ln ($ Roads p.c.) & $\Delta \ln ($ Tel. Lines p.c.) & $\begin{array}{c}\Delta(\% \text { People Access } \\
\text { Sanitation Facilities })\end{array}$ & $\begin{array}{c}\Delta(\% \text { People Access } \\
\text { Water })\end{array}$ \\
\hline \multirow{5}{*}{ GDP p.c. growth } & $(1)$ & $(2)$ & $(3)$ & $(4)$ \\
\hline & 2SLS & 2SLS & 2SLS & 2SLS \\
\hline & $0.53 *$ & $0.37^{* *}$ & $6.90^{* * *}$ & $3.26 * *$ \\
\hline & $(0.29)$ & $(0.15)$ & $(1.95)$ & $(1.34)$ \\
\hline & \multicolumn{4}{|c|}{ First Stage for GDP p.c. growth, average past 10 years } \\
\hline & $0.38 * * *$ & $0.30 * * *$ & $0.36^{* * *}$ & $0.36^{* * *}$ \\
\hline OPS & $(0.05)$ & $(0.02)$ & $(0.04)$ & $(0.04)$ \\
\hline Cragg-Donald F-stat & 146.29 & 358.92 & 259.29 & 233.85 \\
\hline Country FE & Yes & Yes & Yes & Yes \\
\hline Year FE & Yes & Yes & Yes & Yes \\
\hline Observations & 808 & 3725 & 2161 & 2143 \\
\hline
\end{tabular}

Note: The method of estimation is two-stage least squares. Huber robust standard errors (shown in parentheses) are clustered at the country level. * Significantly different from zero at the 10 percent significance level, ${ }^{* *} 5$ percent significance level, $* * * 1$ percent significance level.

It is noteworthy that the 2SLS estimates are larger than the OLS estimates. Comparing the 2SLS estimates in columns (1)-(4) of Table 3 to the OLS estimates in columns (1)-(4) of Table 2, one can see that the 2SLS (OLS) estimated coefficients on GDP per capita growth are $0.53(0.09), 0.37(0.33), 6.90(2.12)$, and $3.26(-0.41)$, respectively. The $p$-values of the Hausman test, for which the OLS estimate is equal to the 2SLS estimate, are 0.10, 0.74, 0.01, and 0.01 , respectively.

One possible reason for the larger 2SLS estimates is classical measurement error in GDP per capita growth. Classical measurement error attenuates the OLS estimates towards zero but does not affect the 2SLS estimates. Time-varying omitted variables that have a direct negative (positive) effect on infrastructure growth and a positive (negative) effect on GDP per capita growth also imply that 2SLS estimation produces a larger coefficient on GDP per capita growth than LS estimation. On the other hand, endogeneity bias due to infrastructure growth having a positive effect on GDP per capita growth can not explain the larger 2SLS estimate; this type of bias would imply that OLS is upward biased.

The 2SLS estimates use the change in the international oil price over a 10 -year period multiplied with countries' average GDP shares of oil net exports as an instrument for decadal GDP per capita growth. Panel B of Table 3 shows that this instrument has a highly significant positive effect on GDP per capita growth. The Cragg-Donald F-statistic is well in excess of 10. Hence, the change in the international oil price over a 10 -year period multiplied with countries' average GDP shares of oil net exports is a relevant instrument for decadal GDP per capita growth.

Economically, the positive effect of on the oil price instrument on GDP growth should be interpreted as countries with a larger GDP share of oil net-exports experiencing higher GDP per capita growth due to higher growth in the international oil price. This is the standard terms of trade effect. That this effect is indeed at work is shown in Appendix A Table A1. This table shows that the response of countries' net barter terms of trade to variations in the oil price instrument is positive and significantly different from zero at the 1 percent significance level. $^{6}$

Table 4 presents reduced form estimates of the impact that the oil price instrument has on infrastructure growth. The estimated reduced-form coefficients (standard errors) on the oil price instrument are: $0.21(0.11)$ when the dependent variable is the natural logarithm of roads, see column (1) of Table $4 ; 0.11(0.05)$ when the dependent variable is the natural logarithm of telephone lines, see column (2) of Table 4; 2.61 (1.10) when the dependent variable is the percent of the population with sanitation access, see column (3) of Table 4; and $1.18(0.45)$ when the dependent variable is the percent of population with water access, see column (4) of Table 4 . The reduced-form effects of oil price windfalls on infrastructure are thus positive and significantly different from zero at the conventional significance levels. 
Table 4. Reduced form effects of OPS on infrastructure.

\begin{tabular}{ccccc}
\hline & $\mathbf{( 1 )}$ & $\mathbf{( 2 )}$ & $\mathbf{( 3 )}$ & $\mathbf{( 4 )}$ \\
\hline Dependent Variable Is: & $\boldsymbol{\Delta} \ln ($ Roads p.c.) & $\Delta \ln$ (Tel. Lines p.c.) & $\begin{array}{c}\Delta(\% \text { People Access } \\
\text { Sanitation Facilities) }\end{array}$ & $\begin{array}{c}\Delta(\% \text { People Access } \\
\text { Water) }\end{array}$ \\
\hline OPS & $0.21^{* *}$ & $0.11^{* *}$ & $2.61^{* *}$ & $1.18^{* * *}$ \\
Country FE & $(0.11)$ & $(0.05)$ & $(1.10)$ & $(0.45)$ \\
Year FE & Yes & Yes & Yes & Yes \\
Observations & Yes & Yes & 2161 & 2143 \\
\hline
\end{tabular}

Note: The method of estimation is least squares. Huber robust standard errors (shown in parentheses) are clustered at the country level.

* Significantly different from zero at the 10 percent significance level, ${ }^{* *} 5$ percent significance level, ${ }^{* * *} 1$ percent significance level.

The exclusion restriction in the 2SLS regressions is that the oil price instrument only affects infrastructure growth through its effect on GDP per capita growth. Table 5 provides evidence that this exclusion restriction is likely fulfilled. Table 5 reports 2SLS estimates with an additional instrument: lagged GDP per capita growth. Lagged GDP per capita growth is a pre-determined variable, which means that this variable is exogenous to current infrastructure growth. When lagged GDP per capita growth is used as an additional instrument in the 2SLS estimation, the econometric model is overidentified. I can therefore compute the Hansen J test. The Hansen J test is a joint test of instrument validity; i.e., it tests the hypothesis that the instruments are jointly uncorrelated with the second-stage error term.

Table 5. GDP growth and infrastructure (overidentified 2SLS regressions).

\begin{tabular}{|c|c|c|c|c|}
\hline Dependent Variable Is: & $\Delta \ln$ (Roads p.c.) & $\Delta \ln ($ Tel. Lines p.c.) & $\begin{array}{c}\Delta(\% \text { People Access } \\
\text { Sanitation Facilities })\end{array}$ & $\begin{array}{c}\Delta(\% \text { People Access } \\
\text { Water })\end{array}$ \\
\hline \multirow{4}{*}{ GDP p.c. growth } & $(1)$ & $(2)$ & (3) & $(4)$ \\
\hline & 2SLS & 2SLS & 2SLS & 2SLS \\
\hline & $0.47^{*}$ & $0.62^{* * *}$ & $9.45^{* * *}$ & $2.11 *$ \\
\hline & $(0.28)$ & $(0.08)$ & $(3.51)$ & $(1.30)$ \\
\hline Cragg-Donald F-Stat & 233.47 & 3271.56 & 107.69 & 1022.35 \\
\hline Hansen J, p-value & 0.23 & 0.48 & 0.16 & 0.26 \\
\hline Country FE & Yes & Yes & Yes & Yes \\
\hline Year FE & Yes & Yes & Yes & Yes \\
\hline Observations & 488 & 2343 & 1175 & 1160 \\
\hline
\end{tabular}

Note: The method of estimation is two-stage least squares. Huber robust standard errors (shown in parentheses) are clustered at the country level. The excluded instruments are OPS and lagged GDP p.c. growth. * Significantly different from zero at the 10 percent significance level, ** 5 percent significance level, ${ }^{* *} 1$ percent significance level.

Table 5 shows that, for all specifications, the $p$-values from the Hansen $\mathrm{J}$ test are in excess of 0.1 . There is therefore no evidence that the instruments violate the exclusion restriction. Importantly, the 2SLS estimates in Table 5-that use both OPS and lagged GDP per capita growth as excluded instruments-yield a significant positive effect of GDP per capita growth on infrastructure growth. In Table 5, the Cragg-Donald statistic is well in excess of 19.93 so that, according to Stock and Yogo (2005), one can reject the hypothesis that the IV size distortion is larger than 10 percent at the 5 percent significance level.

Table 6 shows that there is a significant positive effect of GDP per capita growth on infrastructure growth when the instrument is constructed as the change in the international oil price over a 10-year period times the 1970 value of countries' GDP shares of oil netexports. For example, in column (1) of Table 6, where the dependent variable is the change in the natural logarithm of roads, the estimated 2SLS coefficient (standard error) on GDP per capita growth is $0.89(0.34)$. The Cragg-Donald statistic is well in excess of 10 so that, according to Stock and Yogo (2005), the 2SLS regression is based on a strong instrument. 
Table 6. GDP growth and infrastructure (using 1970 Net-Export GDP shares of oil to construct the OPS instrument).

\begin{tabular}{|c|c|c|c|c|}
\hline Dependent Variable Is: & $\Delta \ln ($ Roads p.c.) & $\Delta \ln ($ Tel. Lines p.c.) & $\begin{array}{c}\Delta(\% \text { People Access } \\
\text { Sanitation Facilities })\end{array}$ & $\begin{array}{c}\Delta(\% \text { People Access } \\
\text { Water })\end{array}$ \\
\hline \multirow{4}{*}{ GDP p.c. growth } & $(1)$ & $(2)$ & $(3)$ & $(4)$ \\
\hline & 2SLS & 2SLS & 2SLS & 2SLS \\
\hline & $0.89^{* * *}$ & $0.43 * *$ & $11.39 * *$ & $3.63^{* * *}$ \\
\hline & $(0.34)$ & $(0.21)$ & $(5.85)$ & $(1.00)$ \\
\hline Cragg-Donald F-Stat & 112.57 & 153.68 & 72.35 & 10.36 \\
\hline Country FE & Yes & Yes & Yes & Yes \\
\hline Year FE & Yes & Yes & Yes & Yes \\
\hline Observations & 774 & 2027 & 1788 & 1695 \\
\hline
\end{tabular}

Note: The method of estimation is two-stage least squares. Huber robust standard errors (shown in parentheses) are clustered at the country level. The excluded instrument is OPS, constructed as the change in the international oil price over a 10-year period times countries' 1970 net-export GDP shares of oil. * Significantly different from zero at the 10 percent significance level, ** 5 percent significance level, ${ }^{* * *} 1$ percent significance level.

Table 7 documents that the positive effect of GDP per capita growth on transportation and telecommunications infrastructure is robust to using alternative measures of transportation and telecommunications infrastructure. In my baseline regressions, following Calderón et al. (2015), I used as a measure of transportation infrastructure the total network of roads; for telecommunications infrastructure, my main measure was telephone lines per capita.

Table 7. GDP growth and infrastructure (alternative measures of transportation and telecommunications infrastructure).

\begin{tabular}{ccccc}
\hline Dependent Variable Is: & $\boldsymbol{\Delta}(\%$ Paved Roads) & $\begin{array}{c}\Delta \ln (\text { Railway Lines } \\
\text { p.c) }\end{array}$ & $\begin{array}{c}\Delta \ln (\text { Mobile Phones } \\
\text { p.c.) }\end{array}$ & $\Delta \ln ($ Internet Users p.c) \\
\hline & $(1)$ & $(2)$ & $(3)$ & $(4)$ \\
GDP p.c. growth & $41.01^{* *}$ & $2 S L S$ & $3.12^{*}$ & $5.81^{* * *}$ \\
Cragg-Donald F-Stat & $(17.71)$ & $4.38^{* *}$ & $(1.77)$ & $(1.16)$ \\
Country FE & 35.33 & $(0.41)$ & 85.64 & 183.80 \\
Year FE & Yes & 70.60 & Yes & Yes \\
Observations & Yes & Yes & 1979 & 1668 \\
\hline
\end{tabular}

Note: The method of estimation is two-stage least squares. Huber robust standard errors (shown in parentheses) are clustered at the country level. The excluded instrument is OPS. * Significantly different from zero at the 10 percent significance level, ${ }^{* *} 5$ percent significance level, *** 1 percent significance level.

In columns (1) and (2) of Table 7, I report results for two alternative measures of transportation infrastructure: the percentage of paved roads and the total network of railways lines. From columns (1) and (2) of Table 7, one can see that the estimated effect of GDP growth on these alternative measures of transportation infrastructure is positive and significantly different from zero at the conventional significance levels.

In columns (3) and (4) of Table 7, the two alternative measures of telecommunications infrastructure are mobile phones per capita and internet users per capita, respectively. One can see from columns (3) and (4) of Table 7 that GDP growth has a significant positive effect on both of these variables. The estimated effect of GDP growth on mobile phones per capita is significantly different from zero at the 10 percent significance level. The estimated effect of GDP growth on internet users per capita is significantly different from zero at the 10 percent significance level.

\subsection{Insignificant Effects in Anocracies}

The main result in the previous section was that, on average, GDP per capita growth has a significant positive effect on infrastructure growth. This section shows that, in anocracies, the effect of GDP per capita growth on infrastructure growth is quantitatively small and statistically insignificant. 
Consider an econometric model that includes an interaction term between GDP per capita growth and (lagged) anocracy:

$$
\begin{aligned}
& \Delta \ln \left(\text { Infrastructure }_{i t}\right)=a^{\prime}{ }_{i}+b^{\prime}{ }_{t}+\alpha^{\prime} \Delta \ln (\text { GDP p.c.it })+\gamma \Delta \ln (\text { GDP p.c.it })^{*} \text { Anocracy }_{i t-1} \\
& +\delta \text { Anocracy }_{\mathrm{it}-1}+\mathrm{e}_{\mathrm{it}}^{\prime}
\end{aligned}
$$

In the above model, $\gamma+\alpha^{\prime}$ measures the effect of GDP per capita growth on infrastructure growth in anocracies; the difference in the effect of GDP per capita growth on infrastructure growth between anocracies and non-anocracies is $\gamma$.

Estimates of the above model are presented in Table 8. Three main results are visible from Table 8 . First, $\gamma$ is negative and significantly different from zero for all four measures of infrastructure. Second, the overall effect of GDP p.c. growth on infrastructure growth in anocracies, $\gamma+\alpha^{\prime}$, is quantitatively small and statistically insignificant. Third, the effect in non-anocracies is positive and highly significant. For example, in column (1), the estimates imply that, in non-anocracies, the effect of a one percentage point increase in GDP per capita growth increases the growth rate of roads by around 1.06 percentage points ( $p$-value $0.024)$; in anocracies, this effect is quantitatively much smaller, around -0.05 percentage points, and not significantly different from zero at the conventional significance levels ( $p$-value of 0.88). ${ }^{7}$

\begin{tabular}{|c|c|c|c|c|}
\hline Dependent Variable Is: & $\Delta \ln ($ Roads p.c.) & $\Delta \ln ($ Tel. Lines p.c.) & $\begin{array}{c}\Delta(\% \text { People Access } \\
\text { Sanitation Facilities })\end{array}$ & $\begin{array}{c}\Delta(\% \text { People Access } \\
\text { Water })\end{array}$ \\
\hline \multirow{4}{*}{ GDP p.c. growth } & $(1)$ & $(2)$ & $(3)$ & $(4)$ \\
\hline & 2SLS & 2SLS & 2SLS & 2SLS \\
\hline & $1.06^{* *}$ & $0.54^{* * *}$ & $11.24^{* * *}$ & $4.61^{* * *}$ \\
\hline & $(0.47)$ & $(0.20)$ & $(3.73)$ & $(1.49)$ \\
\hline GDP p.c. growth * Lagged & -1.11 * & $-0.68 *$ & $-7.64^{* *}$ & $-3.91^{* *}$ \\
\hline Anocracy & $(0.62)$ & $(0.39)$ & $(3.77)$ & $(1.66)$ \\
\hline \multirow{2}{*}{ Lagged Anocracy } & 0.01 & $0.03^{* * *}$ & 0.05 & 0.02 \\
\hline & $(0.01)$ & $(0.01)$ & $(0.04)$ & $(0.04)$ \\
\hline Cragg-Donald F-Stat & 14.08 & 49.43 & 74.79 & 60.74 \\
\hline Country FE & Yes & Yes & Yes & Yes \\
\hline Year FE & Yes & Yes & Yes & Yes \\
\hline Observations & 808 & 3725 & 2161 & 2143 \\
\hline
\end{tabular}

Table 8. GDP growth, anocracy, and infrastructure (interaction model).

Note: The method of estimation is two-stage least squares. Huber robust standard errors (shown in parentheses) are clustered at the country level. The excluded instruments are OPS and the interaction between OPS and lagged anocracy. * Significantly different from zero at the 10 percent significance level, ${ }^{* *} 5$ percent significance level, ${ }^{* * *} 1$ percent significance level.

Another way to see that the effect of GDP per capita growth on infrastructure growth is positive and significant in the sample of non-anocracies, but insignificant in anocracies, is by splitting the sample into two groups. Panel A of Table 9 reports 2SLS estimates for the group of non-anocracies; Panel B of that same table reports 2SLS estimates for the group of anocracies. ${ }^{8}$ For non-anocracies, the estimated effects of GDP growth on infrastructure growth are positive and significantly different from zero at the conventional significance levels. For example, in column (1) of Panel A in Table 9, the estimated 2SLS coefficient (standard error) on GDP per capita growth is $0.81(0.42)$. The estimate can be interpreted as follows: in non-anocracies, a one percentage point increase in GDP per capita growth increases the growth rate of roads by around 0.8 percentage points. In anocracies, the effect of GDP per capita growth on infrastructure growth is quantitatively much smaller and statistically insignificant: from column (1) of Panel B in Table 9, one can see that the 2SLS coefficient (standard error) on GDP per capita growth is $-0.12(0.69)$. 
Table 9. GDP growth, anocracy, and infrastructure (sample split).

\begin{tabular}{|c|c|c|c|c|}
\hline Dependent Variable Is: & $\Delta \ln ($ Roads p.c.) & $\Delta \ln ($ Tel. Lines p.c.) & $\begin{array}{c}\Delta(\% \text { People Access } \\
\text { Sanitation Facilities })\end{array}$ & $\begin{array}{c}\Delta(\% \text { People Access } \\
\text { Water })\end{array}$ \\
\hline & $(1)$ & $(2)$ & $(3)$ & $(4)$ \\
\hline & 2SLS & 2SLS & 2SLS & 2SLS \\
\hline & \multicolumn{4}{|c|}{ Panel A: Non-Anocracies } \\
\hline GDP ns orowth & $0.81 * *$ & $0.59^{* * *}$ & $9.23^{* * *}$ & $4.38^{* * *}$ \\
\hline GDP p.c. growth & $(0.42)$ & $(0.22)$ & $(3.43)$ & $(1.48)$ \\
\hline Cragg-Donald F-Stat & 101.69 & 305.59 & 213.66 & 180.86 \\
\hline Observations & 488 & 2343 & 1175 & 1160 \\
\hline Country FE & Yes & Yes & Yes & Yes \\
\hline \multirow[t]{2}{*}{ Year FE } & Yes & Yes & Yes & Yes \\
\hline & \multicolumn{4}{|c|}{ Panel B: Anocracies } \\
\hline CDP ns orouth & -0.12 & 0.52 & 4.92 & 4.24 \\
\hline GDP p.c. growth & $(0.69)$ & $(0.71)$ & $(3.83)$ & $(4.13)$ \\
\hline Cragg-Donald F-Stat & 25.93 & 32.36 & 43.90 & 37.93 \\
\hline Observations & 260 & 1062 & 761 & 760 \\
\hline Country FE & Yes & Yes & Yes & Yes \\
\hline Year FE & Yes & Yes & Yes & Yes \\
\hline
\end{tabular}

Note: The method of estimation is two-stage least squares. Huber robust standard errors (shown in parentheses) are clustered at the country level. * Significantly different from zero at the 10 percent significance level, ${ }^{* *} 5$ percent significance level, ${ }^{* *} 1$ percent significance level.

The estimated coefficient $\alpha^{\prime}$ in the interaction model of equation $\left(1^{\prime}\right)$ measures the average effect of GDP per capita growth on infrastructure growth in non-anocracies, i.e., in countries that are either democracies or autocracies (as defined according to Polity IV). One may wonder whether the effect of GDP per capita growth on infrastructure growth is the same in democracies and autocracies. In order to explore this issue, I report in Table 10 estimates from an econometric model that includes two interaction terms: one between GDP per capita growth and an indicator that is unity in democracies, and another interaction term between GDP per capita growth and an indicator that is unity in anocracies. Table 10 shows that GDP per capita growth has a significant positive effect on infrastructure growth in both autocracies and democracies. The estimated coefficients on GDP per capita growth are positive and significantly different from zero for all four measures of infrastructure growth. For roads, telephones lines and water infrastructure, the estimated coefficients on the interaction between GDP per capita growth and the democracy indicator are not significantly different from zero at the conventional significance levels. This suggests that there are no systematic differences between autocracies and democracies with regard to the impact that GDP per capita growth has on infrastructure growth. When the dependent variable is sanitation facilities, the estimated coefficient on the interaction between GDP per capita growth and the democracy indicator is negative and significantly different from zero at the 5 percent level. Nevertheless, for democracies, the effect of GDP per capita growth on sanitation infrastructure is positive and significantly different from zero: for democracies, the marginal effect is 6.77 and has a $p$-value of 0.00 . 
Table 10. GDP growth, anocracy, and infrastructure: (interaction model with anocracy and democracy).

\begin{tabular}{|c|c|c|c|c|}
\hline Dependent Variable Is: & $\Delta \ln ($ Roads p.c.) & $\Delta \ln ($ Tel. Lines p.c.) & $\begin{array}{c}\Delta(\% \text { People Access } \\
\text { Sanitation Facilities })\end{array}$ & $\begin{array}{c}\Delta(\% \text { People Access } \\
\text { Water })\end{array}$ \\
\hline \multirow{4}{*}{ GDP p.c. growth } & $(1)$ & $(2)$ & (3) & $(4)$ \\
\hline & 2SLS & 2SLS & 2SLS & 2SLS \\
\hline & $0.95 * *$ & $0.54^{* * *}$ & $11.32^{* * *}$ & $4.54^{* * *}$ \\
\hline & $(0.42)$ & $(0.20)$ & $(3.82)$ & $(1.12)$ \\
\hline GDP p.c. growth * Lagged & $-0.89 *$ & -0.70 * & $-8.07 *$ & $-4.14^{* * *}$ \\
\hline Anocracy & $(0.50)$ & $(0.39)$ & $(4.16)$ & $(1.46)$ \\
\hline GDP p.c. growth * Lagged & -0.08 & -0.06 & $-4.55 *$ & -2.48 \\
\hline Democracy & $(0.26)$ & $(0.10)$ & $(2.34)$ & $(5.02)$ \\
\hline \multirow{2}{*}{ Lagged Anocracy } & 0.02 & $0.04^{* * *}$ & 0.08 & 0.01 \\
\hline & $(0.02)$ & $(0.01)$ & $(0.07)$ & $(0.05)$ \\
\hline \multirow{2}{*}{ Lagged Democracy } & -0.01 & $0.02 * *$ & 0.08 & -0.06 \\
\hline & $(0.02)$ & $(0.01)$ & $(0.07)$ & $(0.08)$ \\
\hline Cragg-Donald F-Stat & 31.88 & 17.29 & 23.63 & 14.95 \\
\hline Country FE & Yes & Yes & Yes & Yes \\
\hline Year FE & Yes & Yes & Yes & Yes \\
\hline Observations & 808 & 3725 & 2161 & 2143 \\
\hline
\end{tabular}

Note: The method of estimation is two-stage least squares. Huber robust standard errors (shown in parentheses) are clustered at the country level. * Significantly different from zero at the 10 percent significance level, ${ }^{* *} 5$ percent significance level, ${ }^{* *} 1$ percent significance level.

\section{Conclusions}

This paper provided estimates of the effect that GDP per capita growth has on infrastructure growth. Using instrumental variables regressions, I found two main results. First, in autocracies and democracies, an increase in GDP per capita growth has a significant positive effect on infrastructure growth. Second, in anocracies, GDP per capita growth has no significant effect on infrastructure growth.

Infrastructure facilitates the exchange of goods and services. Infrastructure is thus very important for the economic development of a country. When a country experiences an exogenous increase in its growth rate of GDP per capita, a political leader faces the following decision problem, which I describe here in simplified form to highlight the main trade-off: option one is to invest the additional income in infrastructure (which implies costs that mostly materialize in the present, i.e., costs associated with the installation of infrastructure vs. benefits that materialize in the future); the other option is simply to use the additional income to increase consumption (which has benefits in terms of increased utility from consumption in the present but no benefits in the future).

An anocracy is a regime that mixes democratic with autocratic features. According to Fearon and Laitin (2003, p. 81), a mixed-up political regime "is likely to indicate political contestation among competing forces and, in consequence, state incapacity". There is a large body of work in political science that shows that anocracies are more prone to civil war than autocracies and democracies. My paper is related to this literature. I presented empirical results on the effect that GDP growth has on infrastructure growth, and showed that the political regime affects this relationship. My results are novel and important.

One important lesson from this paper's empirical analysis is this: in order for an exogenous income gain to translate into policies that lead to sustained GDP growth, the political institutions have to be stable-either democratic or autocratic - but not anocratic. It is not so much about whether political leaders are selected through free and fair elections or whether there exists political competition. Dictators, too, can implement policies that are good for long-run growth. What matters is the persistence of the political regime.

Funding: This research received no external funding.

Institutional Review Board Statement: Not applicable.

Informed Consent Statement: Not applicable. 
Data Availability Statement: See the main text for data sources.

Conflicts of Interest: The authors declare no conflict of interest.

\section{Appendix A}

Table A1. Effects of OPS on the terms of trade.

\begin{tabular}{ccc}
\hline & $\mathbf{( 1 )}$ & $\mathbf{( 2 )}$ \\
\hline Dependent Variable is: & $\Delta($ Terms of Trade Index $)$ & $\Delta \ln$ (Terms of Trade Index) \\
OPS & $0.59^{* * *}$ & $0.52^{* * *}$ \\
Country FE & $(0.13)$ & $(0.11)$ \\
Year FE & Yes & Yes \\
Observations & Yes & Yes \\
\hline
\end{tabular}

Note: The method of estimation is least squares. Huber robust standard errors (shown in parentheses) are clustered at the country level. * Significantly different from zero at the 10 percent significance level, ${ }^{* *} 5$ percent significance level, $* * * 1$ percent significance level.

Table A2. GDP growth and infrastructure (mean group estimates).

\begin{tabular}{ccccc}
\hline Dependent Variable Is: & $\boldsymbol{\Delta} \mathbf{l n}$ (Roads p.c.) & $\boldsymbol{\Delta} \mathbf{l n}$ (Tel. Lines p.c.) & $\begin{array}{c}\Delta(\% \text { People Access } \\
\text { Sanitation Facilities) }\end{array}$ & $\begin{array}{c}\Delta(\% \text { People Access } \\
\text { Water Rural) }\end{array}$ \\
\hline & $(1)$ & $(2)$ & $(3)$ & $(4)$ \\
MG & MG & $2.12 * *$ & -0.41 \\
GDP p.c. growth & 0.09 & $0.33 * * *$ & $(0.79)$ & $(0.80)$ \\
Country FE & $(0.10)$ & $(0.08)$ & Yes & Yes \\
Year FE & Yes & Yes & Yes & Yes \\
Observations & Yes & 3725 & 2161 & 2143 \\
\hline
\end{tabular}

Note: Coefficients (standard errors) are obtained from the Pesaran and Smith (1995) mean group estimator. * Significantly different from zero at the 10 percent significance level, ${ }^{* *} 5$ percent significance level, ${ }^{* * *} 1$ percent significance level.

\section{Notes}

1 See, for example, (World Bank 2004).

2 See, for example, (Acemoglu et al. (2001); Glaeser et al. (2004); Albuoy (2012); Acemoglu et al. (2018)).

3 Polity IV is a widely used database in the economic and political science literature, see, for example, (Acemoglu et al. (2018); Burke and Leigh (2010); Brueckner and Ciccone (2011); Brueckner et al. (2013)).

4 The value of 10 (17) for the first stage F-statistic on the instrument allows to reject the hypothesis that the size distortion in the second stage is larger than 15 (10) percent at the 5 percent significance level (Stock and Yogo 2005).

5 Appendix A Table A1 shows that the Pesaran and Smith (1995) mean group estimator produces similar results.

6 I do not use countries' net barter terms of trade as an instrument for GDP per capita growth because this variable is constructed using time-varying prices and quantities; time-series variation in exports and imports of goods and services are not exogenous to countries' GDP per capita growth or infrastructure growth.

7 The instruments in Table 8 are OPS and the interaction between OPS and lagged anocracy. These variables are relevant instruments for GDP per capita growth and the interaction between GDP per capita growth and lagged anocracy: the Cragg-Donald statistic is well in excess of 7.03 so that, according to (Stock and Yogo (2005)), the hypothesis of the IV size distortion being larger than 10 percent can be rejected at the 5 percent significance level.

8 In both panels the instrument is the OPS variable. This variable is a relevant instrument for GDP per capita growth in both the non-anocracy and anocracy sample; i.e., it has a highly significant positive effect on GDP per capita growth and the Cragg-Donald F-statistic is well in excess of 10. 


\section{References}

Acemoglu, Daron, Simon Johnson, and James A. Robinson. 2001. The Colonial Origins of Comparative Development: An Empirical Investigation. American Economic Review 91: 1369-401. [CrossRef]

Acemoglu, D., S. Naidu, P. Restrepo, and J. Robinson. 2018. Democracy Does Cause Growth. Journal of Political Economy 127: 47-100. [CrossRef]

Albuoy, David Y. 2012. The Colonial Origins of Comparative Development: An Empirical Investigation: Comment. American Economic Review 102: 3059-76. [CrossRef]

Alexeev, Michael, and Robert Conrad. 2009. The Elusive Curse of Oil. Review of Economics and Statistics 91: 586-98. [CrossRef]

Brueckner, Markus, and Antonio Ciccone. 2011. Rain and the Democratic Window of Opportunity. Econometrica 79: 923-47. [CrossRef]

Brueckner, Markus, Antonio Ciccone, and Andrea Tesei. 2013. Oil Price Shocks, Income, and Democracy. Review of Economics and Statistics 94: 389-99. [CrossRef]

Burke, Paul J., and Andrew Leigh. 2010. Do Output Contractions Trigger Democratic Change? American Economic Journal: Macroeconomics 2: 124-57. [CrossRef]

Calderón, César, Enrique Moral-Benito, and Luis Servén. 2015. Is Infrastructure Capital Productive? A Dynamic Heterogenous Approach. Journal of Applied Econometrics 30: 177-98. [CrossRef]

Donaldson, Dave. 2018. Railroads of the Raj. Estimating the Impact of Transportation Infrastructure. American Economic Review 108: 899-934. [CrossRef]

Fearon, James, and David Laitin. 2003. Ethnicity, Insurgency, and Civil War. American Political Science Review 97: 75-90. [CrossRef]

Feenstra, Robert C., Robert E. Lipsey, Haiyan Deng, Alyson C. Ma, and Hengyong Mo. 2004. World Trade Flows: 1962-2000. NBER Working Paper no. 11040. Boston: NBER.

Glaeser, Edward L., Rafael La Porta, Florencio Lopez-de-Silanes, and Andrei Shleifer. 2004. Do Institutions Cause Growth? Journal of Economic Growth 9: 271-303. [CrossRef]

Haber, Stephen, and Victor Menaldo. 2011. Do Natural Resources Fuel Authoritarianism? American Political Science Review 105: 1-26. [CrossRef]

Hamilton, J. 2013. Historical Oil Shocks. In Routledge Handbook of Major Events in Economic History. Edited by Randall E. Parker and Robert Whaples. New York: Routledge Taylor and Francis Group, pp. 239-65.

Heston, Alan, Robert Summers, and Bettina Aten. 2012. Penn World Table Version 7.1. Philadelphia: Center for International Comparisons of Production, Income and Prices at the University of Pennsylvania.

IADB. (Inter-American Development Bank). 2013. Too Far To Export: Domestic Transport Costs and Regional Export Disparities in Latin America and the Caribbean. Washington: IADB.

Keefer, Phillip, and Stephen Knack. 2007. Boondoggles, rent-seeking, and political checks and balances: Public investment under unaccountable governments. Review of Economics and Statistics 89: 566-72. [CrossRef]

Pesaran, Hashem M., and Ron Smith. 1995. Estimating long-run relationships from dynamic heterogeneous panels. Journal of Econometrics 68: 79-113. [CrossRef]

Polity IV. 2013. Political Regime Characteristics and Transitions, 1800-2013. Available online: http://www.systemicpeace.org/ inscrdata.html (accessed on 27 September 2021).

Pritchett, Lant. 2000. The tyranny of concepts: CUDIE (cumulated, depreciated, investment effort) is not capital. Journal of Economic Growth 5: 361-84. [CrossRef]

UNCTAD. 2011. United Nations Conference on Trade and Development, Commodity Price Series. Available online: https://unctad. org/statistics (accessed on 27 September 2021).

UN. (United Nations Economic and Social Council and United Nations Economic Commission for Africa). 2009. The Transport Situation in Africa. Addis Ababa: Ethiopia, Sixth Session of the Committee on Trade, Regional Cooperation and Integration. Available online: https:/ / repository.uneca.org/handle/10855/3252 (accessed on 27 September 2021).

Ross, Michael L. 2012. The Oil Curse: How Petroleum Wealth Shapes the Development of Nations. Princeton: Princeton University Press.

Stock, James H., and Motohiro Yogo. 2005. Testing for Weak Instruments in Linear IV Regression. In Identification and Inference for Econometric Models: Essays in Honor of Thomas Rothenberg. Edited by D. Andrews and J. Stock. Cambridge: Cambridge University Press, pp. 80-108.

World Bank. 2004. The Challenge of Financing Infrastructure in Developing Countries. Washington: Global Development Finance, pp. 149-63.

World Bank. 2009. World Development Report: Reshaping Economic Geography. Washington: World Bank.

World Bank. 2013. World Development Indicators. Available online: https://databank.worldbank.org/source/world-developmentindicators (accessed on 27 September 2021). 